\title{
Macro-economic Models: Comparative Analysis of Strategies and Long Term Outlook for Growth and Poverty Reduction Among ECOWAS Member Countries
}

\author{
Ousmane Badiane, Sunday P. Odjo, and Fleur Wouterse
}

\section{Introduction}

The Common Agricultural Policy of ECOWAS (ECOWAP) was adopted in January 2005, following a close consultation among member states and regional professional organizations. The adoption came $<2$ years after the launch of the Comprehensive Africa Agriculture Development Program (CAADP) under the New Partnership for Africa's Development (NEPAD), an initiative of the African Union. In March 2005, ECOWAS organized, in Bamako, Mali, the Regional Implementation Planning Meeting for CAADP in West Africa. The meeting reviewed the objectives, targets, and principles of CAADP and their alignment with ECOWAP, and confirmed the latter as the political as well as institutional framework for the implementation of the former in the West Africa region. In May 2005, ECOWAS and the NEPAD Secretariat developed a joint ECOWAP/CAADP action plan for the period 2005-2010 for the development of the agricultural sector.

In adopting CAADP, African governments had, amongst others, set for their countries a collective goal of achieving a $6 \%$ agricultural growth rate as a key strategy toward achieving the Millennium Development Goal of reducing poverty to $50 \%$ of its 1990 level by 2015 . They had also opted for a partnership framework to mobilize the required funding to achieve the above growth rate, including the allocation by national governments of a budget share of at least $10 \%$ to the agricultural sector. Finally, CAADP also reflects an option for evidence and outcome based planning and implementation in support of an inclusive sectoral review and dialogue process, in line with the broader NEPAD peer review and accountability principle. A key element of ECOWAP/CAADP is, therefore, to

O. Badiane $(\varangle) \cdot$ S.P. Odjo $\bullet$ F. Wouterse

International Food Policy Research Institute, Washington, DC, USA

e-mail: o.badiane@cgiar.org

C. Henning et al. (eds.), Development Policies and Policy Processes in Africa, 
support and add value to the efforts of individual member states, where necessary, to ensure that they meet the above growth, budgetary, and poverty reduction targets and align with the above principles.

An important part of the planning work carried out by the technical teams in individual member states consisted of reviewing past, current, and emerging country efforts against the above objectives. This includes:

1. Examining the recent growth performance of the agricultural sector, as well as future growth and poverty outcomes based on observed trends;

2. Determining how such outcomes compare with the targets established for the sector under the ECOWAP/CAADP agenda and how they compare with the Millennium Development Goal to halve the proportion of people living on less than a dollar a day (MDG1);

3. Measuring the prospects of meeting these targets and analyzing the implications for future sector growth and poverty-reduction strategies;

4. Estimating the long term funding needs to accelerate agricultural growth and achieve the poverty MDG.

The embracing of ECOWAP/CAADP as the centerpiece of poverty-reduction strategies by member states also implies that agriculture and its individual subsectors must play a primary role as leading sources of pro-poor growth at the national and rural levels. Successful implementation of the agenda at the country level should therefore be guided by a good understanding of the impact of sector wide growth and growth within individual agricultural subsectors on income and poverty levels among different categories of rural households and across geographic zones.

To facilitate implementation of ECOWAP/CAADP, the ECOWAS Commission established a task force and mobilized the necessary technical expertise and funding for the preparation of regional and national agricultural investment programs, including US\$9 million of its own funds. The technical preparation of the National Agricultural Investment Plans (NAIPs) was coordinated by the ministries in charge of integration, led by the ministries in charge of agriculture, and carried out by a team of national and regional experts, with assistance from the International Food Policy Research Institute (IFPRI) and the Regional Strategic Analysis and Knowledge Support System (ReSAKSS), established at the International Institute of Tropical Agriculture (IITA).

The current report summarizes the content of the NAIPs as well as the findings of the technical analysis that has guided their formulation. It is organized around the four main questions that constitute the focus of the analytical work to guide country level planning processes. These questions deal with the key sources of agricultural growth and related impact on poverty levels; the extent to which individual countries are on track to meet the CAADP growth and budgetary targets; the required growth rates and expenditure levels to achieve alternative growth and poverty reduction outcomes; and finally the degree of realism of proposed country investment plans to achieve the CAADP growth and budget targets. 


\subsection{What Are the Key Sources of Agricultural Growth and Poverty Reduction in ECOWAS Countries?}

Figures 1 and 2 show the recent growth and poverty reduction performance among ECOWAS countries compared to other African countries. Figure 1 categorizes countries in four groups based on the rates of agricultural growth and poverty reduction at the start of the new millennium. Countries that perform better overall with higher rates of growth $(>6 \%)$ and relatively lower rates of poverty $(<40 \%)$ would occupy the North-West quadrant. The opposite holds for countries in the South-East quadrant. On the whole, the ECOWAS region seems to perform better in terms of recent growth but shows relatively higher average rates of poverty. Between 1999 and 2005, the agricultural sector in the region grew by $5.0 \%$ a year, well above the African average of $3.3 \%$. However, the average poverty rate in the region $(50.2 \%)$ for the same period is higher than the African average (45.6\%). As a result, only two ECOWAS countries, Cape Verde and The Gambia, are found in the North-West corner of Fig. 1. In contrast, a majority of its member countries, eight in all, are assembled in the South-East corner. Figure 2 presents a separate distribution of ECOWAS countries with respect to both past agricultural growth and poverty outcomes: $54 \%$ of countries are in group IV, with growth rates that are below $6 \%$ and poverty rates that exceed $40 \%$.

A recursive dynamic version of the standard IFPRI Lofgren-Harris-Robinson CGE model coupled with a micro-simulation module is used to simulate future agricultural growth and its impact on poverty levels in individual ECOWAS

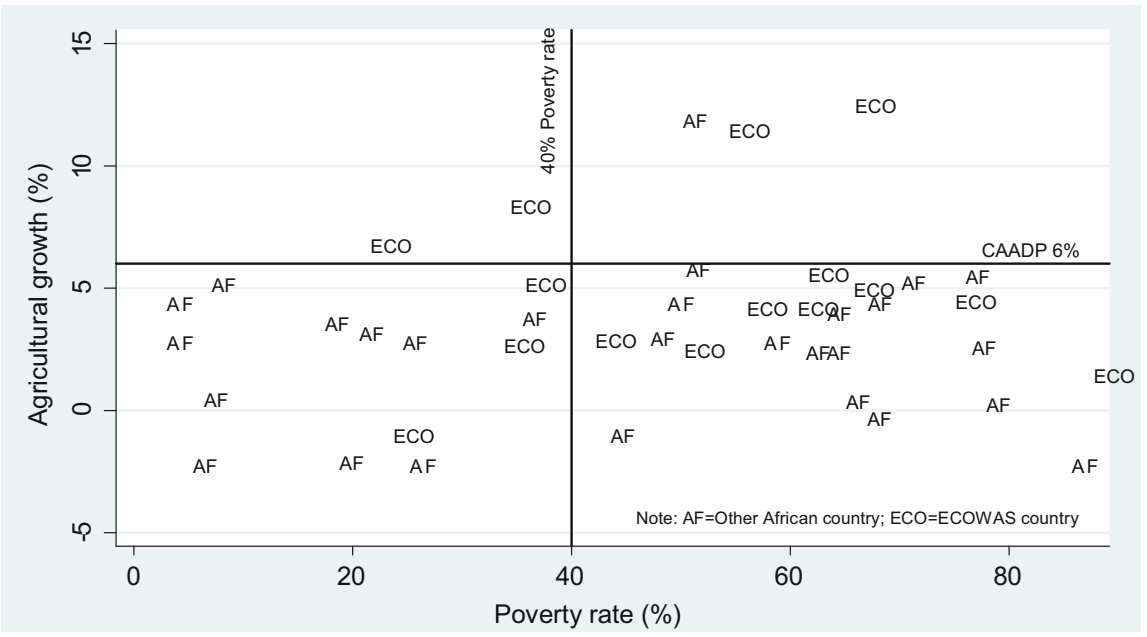

Fig. 1 Position of ECOWAS with respect to CAADP growth and poverty targets (1999-2005). Source: World Development Indicators (2008). Notes: AF indicates a non-ECOWAS African country and ECO an ECOWAS member country 


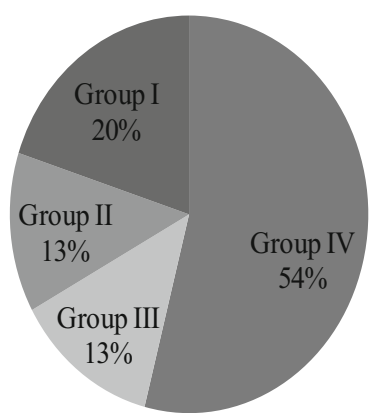

Fig. 2 Distribution of ECOWAS countries with respect to CAADP growth and poverty targets (1999-2005). Source: World Development Indicators (2008). Note: Group I countries have growth rates $<6 \%$ and poverty rates $<40 \%$; group II countries have growth rates $>6 \%$ but poverty rates $<40 \%$; group III countries have growth rates $>6 \%$ and poverty rates $>40 \%$; and group IV countries have $<6 \%$ growth rates and poverty rates $>40 \%$

member countries. ${ }^{1}$ Due to lack of sufficient data, instead of the CGE model a simplified model was used for The Gambia and Liberia. Table 1 summarizes the results of the simulation for 13 ECOWAS member countries. The first two columns compare the simulated reductions in poverty rates resulting from an additional $1 \%$ point increase in the agricultural and non-agricultural rates of growth through to 2015. Although the simulations are run separately for each sector, the prices, activity levels, and factor incomes in the other sectors also change. Hence, the observed decline in poverty rates resulting from growth in one of the sectors in reality also reflects the effect of changes in the remaining sectors. Given that the latter changes emanate from the intersectoral multiplier effects induced by growth in the sector under consideration, we attribute the entire reduction in poverty to that sector. The figures in the Table represent the sectoral shares in the combined decline in poverty rates. The contribution of agricultural growth is consistently higher but diverges considerably across countries: from 10-20\% higher in Benin, Ghana, and Senegal to nearly three times higher in Cape Verde, Côte d'Ivoire, Nigeria, and Togo. For most other countries, the contribution of agriculture is at least $50 \%$ higher compared to other sectors.

The importance of accelerated agricultural growth for poverty reduction in individual countries is demonstrated by the figures in the last two columns. They indicate the contribution by 2015 of an additional $1 \%$ point increase in the rate of agricultural growth to farm incomes and poverty reduction in various ECOWAS countries. Accelerating the rate of agricultural growth as indicated above would raise agricultural GDP (value added) by amounts ranging from US\$21 million in the Gambia to as much as nearly $\$ 400$ million in Mali. The corresponding reduction in the national poverty rates is shown in the last column and hovers around $10 \%$ for

\footnotetext{
${ }^{1}$ See Löfgren et al. (2002) for description and Löfgren (2001) and Thurlow (2004) for other applications of the model.
} 
Table 1 Agricultural growth and poverty reduction in ECOWAS countries

\begin{tabular}{l|l|l|l|l}
\hline & \multicolumn{2}{|l|}{$\begin{array}{l}\text { Sectoral contribution to poverty } \\
\text { reduction resulting from an } \\
\text { additional 1\% point of sectoral } \\
\text { growth by 2015 }\end{array}$} & \multicolumn{2}{l}{$\begin{array}{l}\text { Growth and poverty impact of an additional } \\
\text { 1\% point agricultural growth by 2015 }\end{array}$} \\
\cline { 2 - 5 } & $\begin{array}{l}\text { Due to } \\
\text { Agricultural } \\
\text { growth }\end{array}$ & $\begin{array}{l}\text { Due to } \\
\text { Non-agricultural } \\
\text { growth }\end{array}$ & $\begin{array}{l}\text { Increase in Agricultural } \\
\text { Value Added (US\$ } \\
\text { million) }\end{array}$ & $\begin{array}{l}\text { Reduction in } \\
\text { national poverty } \\
\text { rate (\%) }\end{array}$ \\
\hline Benin & 52.5 & 47.5 & 270.9 & -10.7 \\
\hline Burkina Faso & 60.0 & 40.0 & 215.6 & -10.3 \\
\hline Cape Verde & 72.0 & 28.0 & 27.5 & -25.9 \\
\hline Gambia & 66.7 & 33.3 & 20.8 & -11.1 \\
\hline Ghana & 54.0 & 46.0 & 296.2 & -2.9 \\
\hline Guinea & 59.2 & 40.8 & 57.0 & -10.0 \\
\hline Côte d'Ivoire & 73.0 & 27.0 & 498.5 & -6.5 \\
\hline Liberia & 69.6 & 30.4 & 53.0 & -11.9 \\
\hline Mali & 65.2 & 34.8 & 389.5 & -6.7 \\
\hline Niger & 60.0 & 40.0 & 253.0 & -6.5 \\
\hline Nigeria & 75.0 & 25.0 & NA & NA \\
\hline Senegal & 56.6 & 43.4 & 132.0 & -12.6 \\
\hline Togo & 75.0 & 25.0 & 231.0 & -9.8 \\
\hline
\end{tabular}

Source: Model simulation results for ECOWAS countries. Figures for Nigeria and Ghana are from Diao et al. (2010) and Breisinger et al. (2008), respectively

most countries. It is highest for Cape Verde, Senegal, and Liberia and lowest for Ghana, where it amounts to $<3 \%$.

Although accelerated growth of the agricultural sector as a whole may be the most promising strategy currently available to ECOWAS countries for poverty reduction, such a strategy must also recognize that agricultural sub-sectors do not contribute to the same extent to growth and poverty reduction. The importance of the contribution to growth of each subsector is determined by its initial share in income and employment and its potential for future growth. For each country, the impact on growth and poverty reduction resulting from an incremental $1 \%$ point increase in the rate of growth by 2015 in individual subsectors was simulated. The leading sectors in terms of poverty reduction impact are listed in Table 2. For most countries, the food staples subsector has the greatest potential to contribute to increases in farm incomes and poverty reduction. Livestock also emerges as a strategic subsector, in particular among Sahelian countries. The main message from Table 2 should not be to identify winners but rather to highlight the relative contribution of various subsectors. Given limited growth potential and the geographic as well as demographic implications of growth in individual subsectors, the best strategy would be to marry such concerns with the priority ranking to harness the contribution of a broad range of subsectors. In fact, results from the same simulations show that isolated strategies exclusively targeting a commodity or a subsector would be less effective for poverty reduction than a comprehensive strategy aiming for largely diversified agricultural and non-agricultural growth. 
Table 2 Strategic agricultural subsectors for agricultural growth and poverty reduction

\begin{tabular}{l|l}
\hline Benin & Food crops (maize, roots and tubers) ${ }^{\mathrm{a}}$ \\
\hline Burkina Faso & Cattle and sorghum/millet \\
\hline Cape Verde & Food crops \\
\hline Côte d'Ivoire & Yam, cassava and plantains \\
\hline The Gambia & Cereals (millet/sorghum) ${ }^{\mathrm{a}}$ and livestock \\
\hline Ghana & Root crops and fisheries \\
\hline Guinea & Rice \\
\hline Guinea Bissau & Food crops and fisheries \\
\hline Liberia & Food crops \\
\hline Mali & Food crops (rice; millet/sorghum) ${ }^{\mathrm{a}}$ \\
\hline Niger & Livestock \\
\hline Nigeria & Cassava, Rice \\
\hline Senegal & Livestock and food crops (millet/sorghum; rice) ${ }^{\mathrm{a}}$ \\
\hline Sierra Leone & Cassava, rice \\
\hline Togo & Food crops \\
\hline
\end{tabular}

Source: Model simulation results for ECOWAS countries. Figures for Nigeria and Ghana are from Diao et al. (2010) and Breisinger et al. (2008), respectively

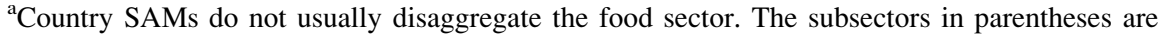
added here only for the purpose of illustrating the leading food commodities in the respective countries

\subsection{Are ECOWAS Countries on Track to Meeting CAADP's Growth and Poverty Reduction Targets by 2015?}

Under current trends or business-as-usual (BAU), agricultural growth among ECOWAS countries is projected to stabilize at around $4-5 \%$ by 2015 , as indicated in the first column of Table $3 .^{2}$ Although these rates are high by historical standards for most countries, they are less than the $6 \%$ targeted under CAADP. Mali and Nigeria are the only countries with expected rates of growth that are close to that target. It can also be seen from the figures in the third column that the projected rates of growth under current trends would not allow any county, except Cape Verde and Ghana, to achieve the MDG1 target of halving poverty by 2015 . Senegal and Sierra Leone and, to a lesser extent, Burkina would come close. In three countries, Benin, Côte d'Ivoire and Liberia, the rate of poverty in 2015 is expected to be, respectively, $18 \%, 37 \%$ and $24 \%$ higher in 2015 compared to 1990 . The problem in these countries is that poverty has continued to rise after 1990 in the face of severe economic contraction in the first and prolonged civil wars in the other two countries. The decline in poverty resulting from projected agricultural growth under current trends would not be sufficient to offset the increase in the poverty rate by 2015.

\footnotetext{
${ }^{2}$ Current trends describes the period leading up to the signing of the CAADP compact, which for most countries refers to the first decade of the 2000s.
} 
Table 3 Long term growth and poverty outcomes under alternative scenarios (\%)

\begin{tabular}{|c|c|c|c|c|c|}
\hline Country & $\begin{array}{l}\text { Agricultural } \\
\text { growth rate by } \\
2015 \text { under } \\
\text { BAU/current } \\
\text { trends }\end{array}$ & $\begin{array}{l}\text { Agricultural } \\
\text { growth rate by } \\
2015 \text { under } \\
\text { pre-CAADP } \\
\text { strategies }\end{array}$ & $\begin{array}{l}\text { Poverty } \\
\text { reduction by } \\
2015 \text { under } \\
\text { current } \\
\text { trends }\end{array}$ & $\begin{array}{l}\text { Poverty } \\
\text { reduction } \\
\text { by } 2015 \\
\text { under } \\
\text { pre-CAADP } \\
\text { strategies } \\
\end{array}$ & $\begin{array}{l}\text { Poverty } \\
\text { reduction by } \\
2015 \text { under } \\
\text { CAADP 6\% } \\
\text { growth target }\end{array}$ \\
\hline Benin & 5.1 & 14.3 & 17.7 & -55.9 & 9.4 \\
\hline Burkina Faso & 5.1 & 5.3 & -40.0 & -44.1 & -50.5 \\
\hline Cape Verde & 2.6 & 5.0 & -61.0 & -75 & -78.0 \\
\hline Gambia & 3.7 & 3.8 & -9.8 & -10.4 & -11.3 \\
\hline Ghana & 4.2 & 7.5 & -50.1 & -54 & -66.0 \\
\hline Guinea & 3.0 & 3.2 & -25.9 & -28.2 & -42.2 \\
\hline Côte d'Ivoire & 2.5 & 2.6 & 37.0 & 35.3 & 10.0 \\
\hline Liberia & 5.0 & $4.0^{\mathrm{a}}$ & 24.3 & 24.2 & 22.6 \\
\hline Mali & 5.5 & 8.5 & -11.0 & -29 & -14.1 \\
\hline Niger & 4.4 & 6.2 & -6.5 & -17.4 & -16.6 \\
\hline Nigeria & 5.7 & 9.5 & -10.0 & $-30.0^{\mathrm{b}}$ & c \\
\hline Senegal & 4.1 & NA & -43.8 & NA & -49.7 \\
\hline Sierra Leone & 4.2 & NA & -42.5 & NA & -47.6 \\
\hline Togo & 4.7 & 5.0 & -17.2 & -19.4 & -26.4 \\
\hline
\end{tabular}

Source: Model simulation results for ECOWAS countries. Figures for Nigeria and Ghana are from Diao et al. (2010) and Breisinger et al. (2008), respectively

NA Not applicable

Notes: ${ }^{\mathrm{a}}$ The rate of growth is projected to decline as the country transitions out of the immediate post-war recovery period (current trends scenario). ${ }^{\mathrm{b}}$ The target year chosen by Nigeria is 2017. ${ }^{\mathrm{c}}$ There were no separate simulations of this scenario, given that the country was already growing at $5.7 \%$ under the current trends scenario

Prior to embracing CAADP, many countries had on-the-shelf strategies that pre-date the signing of the Compact and were at difference stages of readiness for implementation. The implied growth rates under these strategies, assuming that they could be successfully implemented and their declared targets achieved, are listed in the second column of the Table. The rates are universally higher than projected rates under current trends. The only exception is Liberia, for which the scenario under current trends refers to the post-conflict period. For the region as a whole, the average rate of growth for the agricultural sector would increase from under $5 \%$ under status quo to slightly more than $6 \%$, thus meeting the CAADP growth target. However, for several of the countries, such as Benin, Nigeria, and Mali, the implied growth rates are significantly higher than would be expected based on recent performance, hence suggesting a problem of realism of declared investment and growth targets under these strategies. The implied rate of growth is high for Ghana as well, relative to historical records, but is less challenging in absolute terms than the rates for the other three countries. Nevertheless, the projected rates of growth for the majority of countries would still fall well short of the CAADP target of $6 \%$. 
With respect to the goal of poverty reduction, Benin would be the only country to join Ghana and Cape Verde in halving poverty rates below the 1990 levels under the present scenario, as shown in column 4. It is, however, clearly unrealistic to expect Benin's agricultural sector to nearly triple its pre-CAADP rate of growth to $14.3 \%$ a year by 2015 . Strategies for all other countries would imply changes in poverty levels that are significantly below the MDG1 target. And for the two post-conflict countries, Liberia and Côte d'Ivoire, poverty rates would still be considerably higher than their 1990 levels: by nearly 25\% and 35\%, respectively. In contrast, the adoption and successful implementation of strategies and programs that would enable all ECOWAS member countries to achieve the 6\% CAADP growth target would lead to substantial reduction in poverty rates across the region, although less than half of the countries would be expected to reach MDG1 by 2015 (fifth column). The challenge in realizing the poverty MDG by 2015 is made difficult for Benin, Côte d'Ivoire, and Liberia because poverty rates in these countries have continued to rise after 1990 and have not stabilized or started to decline before the end of that decade. In the case of Liberia, the poverty rate jumped from $61 \%$ in 1990 to $84 \%$ in 2007. Under continuation of growth trends during the period leading up to the signing of the CAADP compact, with a rate of 5\%, as shown in the first column, the rate of poverty by 2015 would have fallen by $<10 \%$ points to $76 \%$, still close to $25 \%$ above the 1990 level. Because the rate of growth under current trends is already close to the CAADP target and projected to even decline slightly under implementation of pre-CAADP strategies, the rate of poverty in Liberia is significantly higher than the 1990 level in all of these scenarios.

In Côte d'Ivoire, the rate of poverty rose by $50 \%$ from $32 \%$ in 1993 to $49 \%$ in 2008. The achievable reduction in poverty under the BAU scenario or the implementation of pre-CAADP strategies is $<5 \%$ points for that country. Realization of the CAADP growth targets would have merely brought poverty levels close to their levels of the early 1990s. The increase in poverty during the 1990s was less considerable for Benin. Poverty level estimates in that country rose from slightly more than $25 \%$ in 1990 to $36 \%$ in 2006 . Under the BAU scenario, poverty levels would fall to $30 \%$ by 2015 , corresponding to a decline of about $18 \%$ compared to the 1990 level.

\subsection{How Fast Should ECOWAS Countries Grow to Achieve the Poverty MDG? How Much Would They Have to Spend?}

In order to achieve the goal of halving poverty by 2015, many countries would have to reach double digit rates of growth in the agricultural sector: between around $12 \%$ and $15 \%$ for Benin, Mali, The Gambia, Niger and Côte d'Ivoire, and as much as $26 \%$ for Liberia, as shown in the first column of Table 4 . A history of civil war explains the very serious situation in the latter country. These extremely high growth rates indicate that it will be impossible for these countries to achieve the 
Table 4 Long term agricultural growth and funding requirements

\begin{tabular}{l|l|l|l|l|l}
\hline & $\begin{array}{l}\text { Required } \\
\text { agricultural } \\
\text { growth rate } \\
\text { to achieve } \\
\text { the poverty } \\
\text { MDG target } \\
\text { by 2015 }(\%)\end{array}$ & $\begin{array}{l}\text { Required } \\
\text { agricultural } \\
\text { growth rate } \\
\text { to achieve } \\
\text { the poverty } \\
\text { MDG target } \\
\text { by 2020 }(\%)\end{array}$ & $\begin{array}{l}\text { Required } \\
\text { agricultural } \\
\text { funding growth } \\
\text { rate to achieve } \\
\text { the poverty } \\
\text { MDG target by } \\
\text { Country }\end{array}$ & $\begin{array}{l}\text { Required } \\
\text { agricultural } \\
\text { funding growth } \\
\text { rate to achieve } \\
\text { the poverty } \\
\text { MDG target by } \\
2020(\%)\end{array}$ & $\begin{array}{l}\text { Required } \\
\text { agricultural } \\
\text { funding growth } \\
\text { rate to achieve } \\
\text { CAADP 6\% } \\
\text { target rate by } \\
2015(\%)\end{array}$ \\
\hline Benin & 13.1 & 9.1 & 22.8 & 13.9 & 7.9 \\
\hline Burkina Faso & 7.1 & 5.9 & 11.6 & 9.0 & 9.1 \\
\hline Cape Verde & - & - & - & - & 11.2 \\
\hline Gambia & 14.4 & $8.6^{\mathrm{a}}$ & 99.3 & $59.3^{\mathrm{a}}$ & 19.6 \\
\hline Ghana & - & - & - & - & 21.7 \\
\hline Guinea & 10.3 & 7.5 & 33.5 & 26.5 & 12.3 \\
\hline Côte d'Ivoire & 14.8 & 9.0 & 62.2 & 25.1 & 27.0 \\
\hline Liberia & 26.1 & $14.6^{\mathrm{a}}$ & 117.7 & $65.7^{\mathrm{a}}$ & 27.0 \\
\hline Mali & 12.5 & 8.1 & 45.8 & 13.7 & 8.2 \\
\hline Niger & 11.9 & 9.0 & 25.1 & 18.2 & 26.5 \\
\hline Nigeria & - & $9.5^{\mathrm{a}}$ & - & $23.8^{\mathrm{a}}$ & $4.7^{\mathrm{b}}$ \\
\hline Senegal & - & $6.8^{\mathrm{c}}$ & - & $10.0^{\mathrm{c}}$ & 7.6 \\
\hline Sierra Leone & - & - & - & - & 10.0 \\
\hline Togo & 9.6 & 6.9 & 74.2 & 43.1 & 35.4 \\
\hline So & & & &
\end{tabular}

Source: Model simulation results for ECOWAS countries

Notes: Not applicable as these countries are already on track under current trends to achieving the poverty MDG by 2015 (Cape Verde and Ghana) or scenarios were otherwise not relevant or feasible

${ }^{a}$ Projection years are 2017 for Nigeria and 2025 for The Gambia and Liberia

${ }^{\mathrm{b}}$ For Nigeria, this is the required agricultural spending growth rate to sustain current growth trends, which at $5.7 \%$ is nearly identical to the CAADP target of $6 \%$

${ }^{\mathrm{c}}$ For Senegal, the numbers shown correspond to the required agricultural growth rate and funding growth rate to achieve the government's objective of the reducing poverty rate to $17 \%$ by 2020

poverty reduction goal by 2015 . Some could, however, do so by 2020 , namely Benin, Côte d'Ivoire, Mali and Niger, although all would require growth rates of around 9\%, which by historical standards are still high (Table 3, second column). For The Gambia and Liberia, the poverty MDG could not be achieved by 2020 but could be reached by 2025 , if they were to realize agricultural growth rates of nearly $9 \%$ and $15 \%$, respectively. While it is true that post-conflict countries can sometimes grow rapidly during the recovery phase, whether Liberia would be able to sustain such a high growth rate over a long time is questionable.

The extent of the challenge for many countries in achieving the poverty MDG or the CAADP growth target is also illustrated by the required rise in public funding for the agricultural sector. As shown in the third column of Table 4, the required funding growth rate to achieve the poverty MDG by 2015 is prohibitively high for most countries. The required annual rate of increase in public expenditure remains still extremely high, even if the target date for achieving MDG1 is moved to 2020. For six of the eleven countries for which estimates are available, funding for the 
agricultural sector would have to rise by around $20 \%$ or more annually. The remaining countries would still have to expand funding for the sector by double digit rates or close to that in the case of Burkina Faso. Realization of the MDG poverty target by ECOWAS member countries is therefore not only a question of physically achievable agricultural growth but also a question of financial resource mobilization capacity.

The significance of the financial resources constraint is illustrated by the increase in funding required for achieving the CAADP target of 6\% growth through to 2015. Although the increase in funding may be feasible for several of the countries, it is still quite challenging and would nonetheless not be sufficient to allow any of the countries to realize the poverty MDG, as can be seen from the last columns of Tables 3 and 4 . The only exception would be Burkina Faso. A look at current levels of sectoral funding sheds light on the feasibility of the pace of funding increase that is called for under the various scenarios. Figure 3 below presents the share of agricultural sector funding for the various countries in the latest year for which the information is available. Several countries such as Benin, Côte d'Ivoire, Nigeria, Sierra Leone and Togo are currently allocating the lowest share of country budgets to agriculture. The scope of raising the level of agricultural funding should, a priori, be greater in these countries. For instance, achieving the CAADP growth target by 2015 or MDG1 by 2020 in Benin or Mali would call for annual rates of growth in agricultural funding of around $8 \%$ and $14 \%$, respectively. Starting from agricultural sector budget shares in the range of 9-10\%, there may be some room to achieve such increases in sectoral spending. The scope for expanding agricultural sector spending is greater in the case of Nigeria, which spends currently only about $3 \%$ of

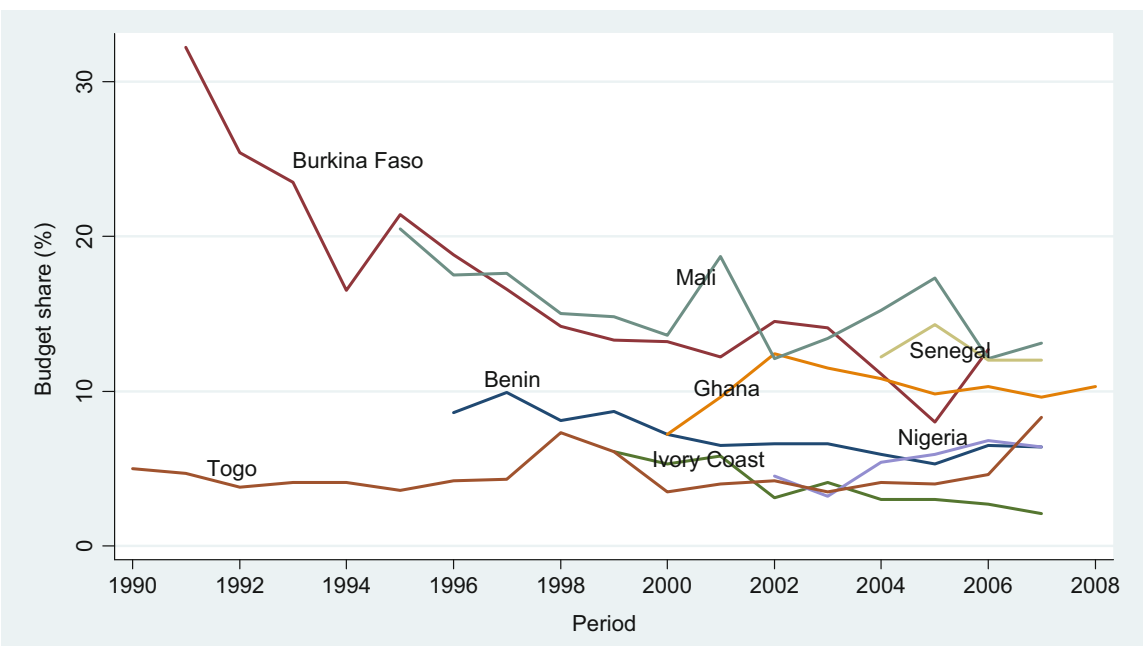

Fig. 3 Trends in pre-compact agricultural sector budget shares (\%). Source: Based on agricultural budget data survey across West Africa countries 
Table 5 Public expenditure allocation to agriculture and efficiency

\begin{tabular}{l|l|l}
\hline & $\begin{array}{l}\text { Agricultural sector budget share at time } \\
\text { of compact signing }(\%)^{\mathrm{a}}\end{array}$ & $\begin{array}{l}\text { Estimated expenditure elasticity } \\
\text { of agricultural growth }\end{array}$ \\
\hline Benin & 8.6 & 0.26 \\
\hline Burkina Faso & 21.2 & 0.24 \\
\hline Cape Verde & 1.3 & 0.11 \\
\hline Gambia & 6.6 & 0.15 \\
\hline Ghana & 4.9 & 0.15 \\
\hline Guinea & 13.7 & 0.25 \\
\hline Côte d'Ivoire & 3 & 0.25 \\
\hline Liberia & 6 & 0.22 \\
\hline Mali & 9.7 & 0.25 \\
\hline Niger & 22.3 & 0.53 \\
\hline Nigeria & 3.4 & 0.39 \\
\hline Senegal & 19.2 & 0.48 \\
\hline Sierra Leone & 2.8 & 0.24 \\
\hline Togo & 3.2 & 0.11
\end{tabular}

Source: Budget shares are from respective country CAADP Roundtable Brochures No. 4 (http:// www.resakss.org); elasticities are based on model simulation results for ECOWAS countries. The average elasticity estimate for Africa by Fan et al. (2008) as a whole is 0.31

${ }^{\mathrm{a} C}$ Current refers to the latest year for which data is available at time of compact signing

its budget on agriculture. The required rate of increase of $24 \%$ of sectoral funding to achieve MDG1 by 2017 should be considered realistic and feasible.

The other challenge related to meeting the funding requirement of achieving the CAADP growth and MDG poverty targets is reflected in the numbers in the last column of Table 5. Out of 13 ECOWAS countries for which estimates are available, only three show an elasticity of agricultural growth with respect to public expenditure that is above the African average of 0.31 estimated by Fan et al. (2008). For many of these countries, therefore, achieving the CAADP growth target by 2015 or MDG1 within the next 10 years would require both an increase in the level and in the efficiency of agricultural sector funding. This is because these countries are already spending relatively high shares of their budgets on agriculture and also have historically recorded relatively lower levels of responsiveness of agricultural growth to public sector spending. Other countries have very little room to raise already very high shares of agricultural spending and thus would need to focus primarily on raising the efficiency of funding to the sector. Burkina Faso, for instance, would need to expand sectoral spending by $<10 \%$ annually to meet the CAADP growth target and realize MDG1 by 2020 (Table 3). However, the country is already allocating more than $20 \%$ of its budget to agriculture (Table 5). On the other hand, the elasticity of agricultural growth with respect to public funding in that country is estimated at 0.24 or $20 \%$ below the average African estimate. Gambia, Liberia, and Togo, on the other hand, are currently spending much less on agriculture but require a significantly larger increase in agricultural spending (above 20\%) to meet either the CAADP growth target or MDG1 by 2020. The three countries also have historically lower expenditure elasticities of growth compared 
to the African average, with estimates of $0.15,0.22$, and 0.11 , respectively. Niger and Senegal are in a peculiar situation characterized by high sector spending shares and above-average public expenditure elasticities of growth but still needing to further increase sectoral funding, albeit moderately in the case of Senegal, to achieve the CAADP growth and MDG1 poverty targets.

The CAADP target of allocating at least $10 \%$ of national budgets to agriculture translates the conviction that achieving the growth target would require most countries to significantly raise the level of funding allocated to the sector. The figures in Table 5 show where individual ECOWAS member countries stand with respect to the budget target. Although the average agricultural sector budget share of $11 \%$ for ECOWAS as a whole is above the CAADP target, there is a wide variation across countries with shares ranging from about 3\% in Sierra Leone to $22 \%$ in Niger.

Five of the 13 countries for which data is available, namely Burkina, Mali, Ghana, Niger and Senegal, have managed to allocate at least $10 \%$ of their budget to agriculture. The first two have had historically high levels of agricultural funding, which is primarily explained by heavy subsidies to the cotton sector. Senegal has recently considerably expanded funding for agriculture under a variety of presidential programs.

The funding levels do not only vary across counties, they have also been unstable over time. More noticeably, they have trended downwards for most countries during the decade and a half preceding the adoption of the CAADP expenditure target. The declining trend has continued in Ghana, Nigeria and Mali up until the time of compact signing, as shown by a comparison of shares in Table 5 and by considering the shares for the three countries at the end of the period shown in Fig. 3. In contrast, Senegal, Burkina, and to a lesser extent Benin have raised sector expenditures going into the CAADP roundtable and the signing of the compact. On the other hand, Togo went from a stable and rising trend in expenditure levels to a sharp drop by the time of the signing of the CAADP compact. The change in trends in the latter country can be explained by the political crisis and interruption of external funding for the sector for most of the 2000s. The continued decline in sectoral funding in Côte d'Ivoire in the period leading up to the signing of the compact can also be explained by the political crisis in that country and its impact on local fiscal resources and domestic services delivery institutions.

The likelihood of countries expanding and sustaining levels of agricultural sector funding is not only a function of political will but also of domestic fiscal capacities. Figure 4 presents domestic resources as a share of total agricultural spending. In most countries, the domestic share represents $60 \%$ or less of total agricultural sectoral spending over the nearly 20 year period covered by the data.

In order to achieve the CAADP budget target by relying only on domestic sources, most countries would have to nearly double their current share of domestic resources in total agricultural spending. The mobilization of external funding will therefore be a critical component of CAADP implementation among ECOWAS countries. This is particularly so for Niger and Burkina, which already allocate a 


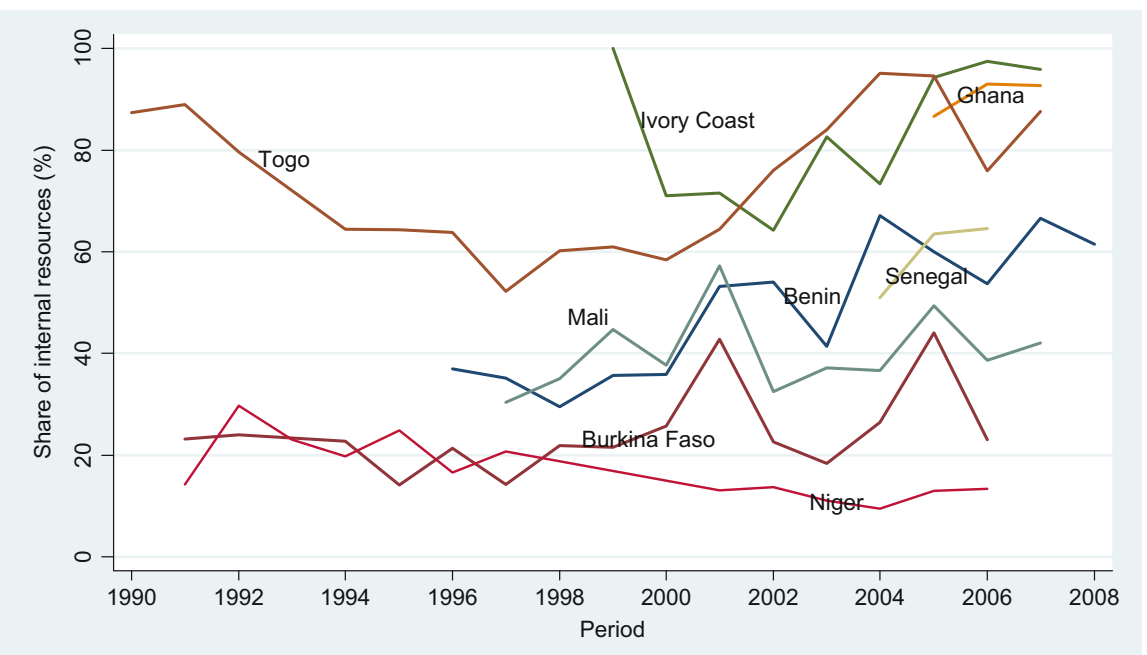

Fig. 4 Share of internal resources in agricultural spending (\%). Source: Based on agricultural budget data survey across West Africa countries

significant share of overall funding to agriculture but rely on external sources for $80 \%$ or more of the funding for agriculture.

In addition to the level and efficiency of funding, the degree of actual budget execution has historically been the third dimension of the problem of effective financing of agricultural growth among African countries. As shown in Fig. 5, the average rate of disbursement of agricultural budgets is distinctly lower than the rate of overall budget execution, which for most countries is in the $80 \%$ range or lower. The exceptions are Burkina and Senegal, which show higher execution rates for agriculture, although it is to be noted that Burkina exhibits an extremely low rate of overall budget execution of $<50 \%$. High performers in terms of agricultural budget disbursement include Senegal, Nigeria and Ghana with execution rates exceeding 90\%; lagging behind are Burkina, Côte d'Ivoire, and Togo. The key message from Fig. 5 is that efforts to increase agricultural funding under CAADP will have to address the constraints to effective budget execution, which appears to be a general problem and not specific to the agricultural sector.

\subsection{How Consistent Are Agricultural Investment Priorities and Related Growth and Poverty Outcomes Among ECOWAS Countries?}

The National Agricultural Investment Plans (NAIPs) are the next step in the CAADP implementation process after the agreement around key policy, budgetary, and partnership priorities during the roundtable. They define specific sub-sector objectives and identify specific activities to be funded. The main priority sectors 


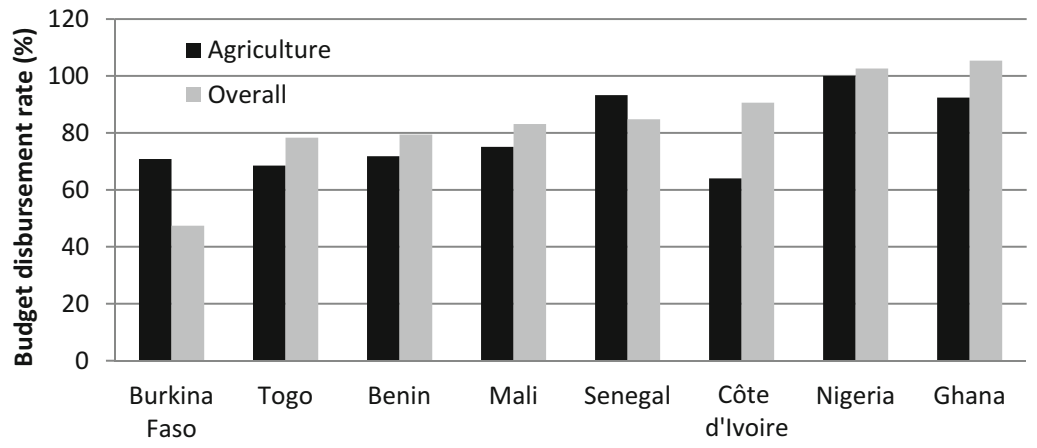

Fig. 5 Agricultural and overall budget disbursement rates (\%; latest year). Source: Based on ReSAKSS survey of agricultural budget data across West Africa countries
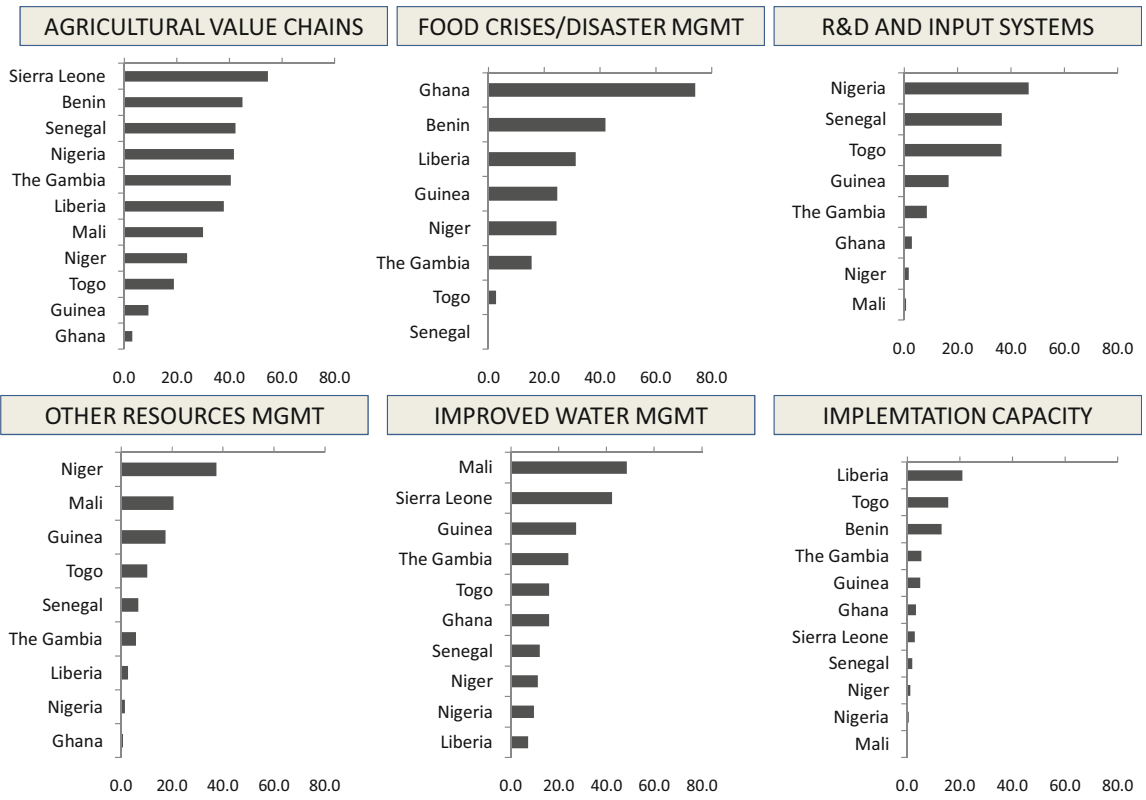

Fig. 6 Common priority areas in country investment plans. Source: Authors using information from various agriculture investment plans

that cut across individual countries are presented in Fig. 6. They cover the following: value chain development; food and other emergency crises and disaster management; research and development, including seeds systems; improved water and other resources management; as well as capacity building for successful implementation. The horizontal bars denote the percentage share of each of these sectors in the overall investment budgets of individual countries. The difference across countries reflects the diverging priorities accorded to individual investment areas by different countries. Although the differences most likely reflect different 
advances in specific areas by different countries, it is interesting to note the wide variations between countries. The overall level of planned investments is shown in the second column of Table 6 . It is in the one billion US\$ range for most countries, and double that amount or more for four countries. It is highest for Ghana and Nigeria, where planned investment levels exceed the US\$5 billion mark. The smallest countries, Cape Verde and Gambia, have, as expected, the smallest levels of planned investments. In addition to defining priority investment areas and investment levels, country investment plans in many cases also specify a given rate of agricultural growth to be achieved. In others, they specify specific investment outcomes such as total areas of land under irrigation or specific crop yields that can be converted to corresponding changes in overall output and translated into sector growth rates.

Ideally, the design of the investment plans should be guided by the results from the analysis of alternative growth and poverty reduction options. The speed of planning and implementation was so high that the growth analysis and planning activities have overlapped, leading to an iterative rather than sequential process in integrating the two sets of activities. In all countries, however, a key step is a consistency analysis that takes place after the first version of the investment plan is completed. The consistency analysis assesses the extent to which investment levels as well as growth and poverty reduction outcomes that are being pursued in individual country investment plans are in line with the alternative long term growth, poverty reduction, and funding requirement scenarios, as well as historical expenditure levels discussed in the previous sections. In carrying out the analysis, proposed investment activities and related crop yields and/or target subsectoral growth rates are fed into the country CGE models to simulate the overall rate of agricultural growth and reduction in poverty levels that would result from individual country NAIPs. The results are then contrasted with the outcomes from the alternative long term scenarios. The comparisons can be as detailed as looking at differences in subsector growth rates and poverty outcomes among targeted geographic areas or demographic groups. ${ }^{3}$

For the current paper, we are considering consistency between target outcomes under investment plans and long term scenarios at the sectoral or national level. The results are summarized in Table 6 and Fig. 6. The Table compares the sectoral growth targets and associated expenditure levels under individual investment plans (first and second columns) with those of the closest long term growth scenario (third and fourth columns). The comparison suggests that in some cases there are significant discrepancies between proposed investment levels and simulated funding requirements for similar rates of growth. As shown by the ratios in the last column, the discrepancies are observed in both directions. For countries such as The Gambia, Mali, Nigeria, and Benin, the investment plans appear to be significantly underfunded in order to deliver the expected growth outcome. In contrast, suggested funding levels for the investment plans appear considerably higher than

\footnotetext{
${ }^{3}$ See IFPRI Discussion Paper No. 1019 by Badiane et al. (2010)
} 
Table 6 NAIP costs versus long term funding benchmarks

\begin{tabular}{|c|c|c|c|c|c|}
\hline & \multicolumn{2}{|c|}{$\begin{array}{l}\text { National Agricultural Investment } \\
\text { Plans (NAIPs) }\end{array}$} & \multicolumn{2}{|c|}{$\begin{array}{l}\text { Comparable pre-compact growth } \\
\text { scenario }\end{array}$} & \multirow[b]{2}{*}{$\begin{array}{l}\text { Cost } \\
\text { ratio }\end{array}$} \\
\hline & $\begin{array}{l}\text { Expected } \\
\text { agricultural } \\
\text { growth rate }(\%)\end{array}$ & \begin{tabular}{|l} 
Cost \\
(million \\
USD)
\end{tabular} & $\begin{array}{l}\text { Expected } \\
\text { agricultural } \\
\text { growth rate }(\%)\end{array}$ & $\begin{array}{l}\text { Cost } \\
\text { (million } \\
\text { USD) }\end{array}$ & \\
\hline & [1] & {$[2]$} & [3] & {$[4]$} & {$[2] /[4]$} \\
\hline Benin & 14.3 & 884.1 & 14.3 & 1276.2 & 0.69 \\
\hline Cape Verde & 6.9 & 96.4 & 6.0 & 51.6 & 1.87 \\
\hline Gambia & 8.0 & 296.6 & 8.6 & 1065.8 & 0.28 \\
\hline Ghana & 5.2 & 5479.5 & 6.9 & 3082.2 & 1.78 \\
\hline Guinea & 10.3 & 1601.2 & 10.3 & 222.0 & 7.21 \\
\hline Liberia & 9.9 & 947.7 & 9.4 & 149.5 & 6.34 \\
\hline Mali & 8.8 & 727.2 & 8.5 & 5376.4 & 0.14 \\
\hline Niger & 7.4 & 2457.0 & 6.4 & 2233.4 & 1.1 \\
\hline Nigeria & 21.0 & 7535.4 & 9.5 & 28563.1 & 0.26 \\
\hline Senegal & 9.7 & 2727.5 & 6.8 & 1771.1 & 1.54 \\
\hline Sierra Leone & 7.0 & 388.0 & 7.1 & 100.6 & 3.86 \\
\hline Togo & 6.8 & 947.2 & 6.7 & 989.3 & 0.96 \\
\hline
\end{tabular}

Source: Respective country investment plans and CAADP Roundtable Brochures No 4 (http:// www.resakss.org)

Note: The comparable growth scenarios for the different countries are summarized below: Benin (PSRSA), Cape Verde (ECOWAP/PDDAA), Gambia (MDG1 by 2025), Ghana [MIC (reaching Middle Income Country status by 2015)], Guinea (MDG1 by 2015), Liberia (MDG1 by 2025), Mali [SDDR (Schéma Directeur de Développement Rural)], Niger [SDR (Stratégie de Développement Rural)], Nigeria (Agricultural TFP growth driven by agricultural expenditure only), Senegal (Government's objective to reduce poverty rate to $17 \%$ by 2020), Sierra Leone [MDG1-2015 (while keeping non-agricultural sectors growing at current rates)], Togo (MDG1 by 2020)

required to meet the growth targets in the case of Sierra Leone, Liberia, and Guinea, and to a lesser extent for Cape Verde, Ghana, and Senegal. Only for Togo and Niger do the suggested funding levels appear to be consistent with projected long term growth outcomes.

The consistency analysis also assesses the degree of realism of pursued poverty reduction outcomes. It does so by comparing targeted poverty reduction levels under the investment plans with projected outcomes under continuation of pre-CAADP trends or business as usual (BAU). The results are plotted in Fig. 7. Benin, Nigeria, and Guinea exhibit the largest potential improvement from successful implementation of country investment plans. The first two however appear to have underfunded their investment plans and are thus less likely to achieve the expected poverty reduction outcome. Gambia and Mali are other countries with underfunded NAIPs, which may not achieve the expected improvement in poverty outcomes. Sierra Leone, Liberia, Guinea, Ghana, and Senegal all have seemingly overfunded NAIPs and should be in a position to realize the expected decline in poverty levels at a lower cost than budgeted under the current investment plans. 


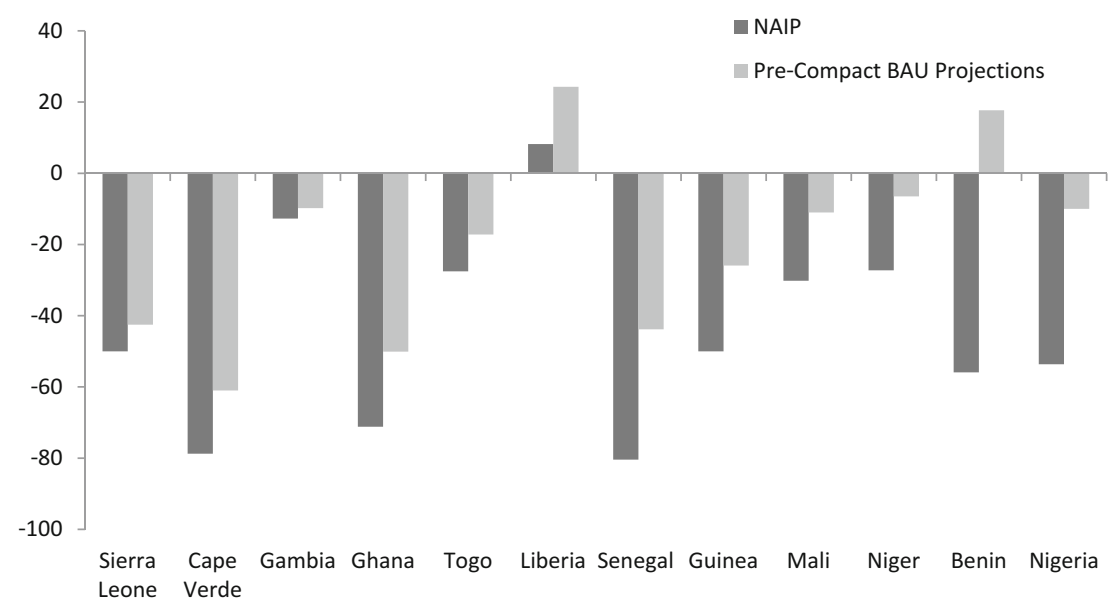

Fig. 7 Decline in poverty rates by 2015 under investment plans compared to pre-compact projections under BAU (\%). Source: Authors' model simulation results for ECOWAS countries

\section{Conclusion}

Overall, there were no data to evaluate post-compact food security trends. It is vital that necessary arrangements are made to regularly update the baseline household survey information so as to facilitate tracking of poverty, food security and distributional impacts of the investment plans.

To ensure high return, investment commitments under the NAIPs must be supported by strong governance and monitored in a timely and transparent fashion. Therefore, it should be of high priority that countries improve policymaking by adopting an evidence-based approach. Such an approach should include review and dialogue mechanisms and knowledge support systems to facilitate benchmarking, mutual learning, and capacity strengthening, which would improve agricultural policy, program design, and implementation. The data available and the knowledge flow observed in the course of CAADP implementation suggests an urgent need to undertake institutional mapping of all actors involved in the policymaking process in the agricultural sector. This analysis should include data collection/gathering, policy analysis, and drafting of policy notes or policy dialogues. There is also a need for a full-fledged monitoring and evaluation framework for the agricultural sector with clear individual and institutional responsibilities. Such an M\&E framework would need to include (i) data processing and policy analysis; (ii) policy dialogue and advocacy; and (iii) a monitoring and evaluation system. 


\section{ANNEX \\ Description of the Model Used to Simulate Long Term Growth and Poverty Reduction Outcomes}

\section{Model Specification and Calibration Data}

We used a Dynamic single-country Computable General Equilibrium (DCGE) model for individual ECOWAS member countries for which a Social Accounting Matrix (SAM) was available. ${ }^{4}$ The model is a recursive dynamic version of the standard IFPRI Lofgren-Harris-Robinson CGE model coupled with a microsimulation module. ${ }^{5}$ Annex provides a mathematical description of the model specifications. It is designed as a set of simultaneous linear and non-linear equations that represent the first order conditions of the profit and utility maximization behaviors of national economic agents, along with key macroeconomic constraints within a period. The model also specifies the process through which the values of some selected exogenous variables are updated to account for changes in population, labor and land supplies, capital accumulation, total factor productivity and government expenditures between successive periods. This kind of model is appropriate for the analysis of the impacts of alternative policy options on agricultural growth and poverty reduction outcomes as it explicitly takes into account the interactions between disaggregated agricultural and non-agricultural sectors and between the national economy and the rest of world while allowing to follow the distribution of income among factors and among households and other institutions.

In each activity of the national economy, production is carried out following a nested technology in which value-added quantity is a Constant Elasticity of Substitution (CES) function of primary factors, while aggregate intermediate input quantity is a Leontief function of specific intermediate inputs from different sectors, and overall activity output is a Leontief function of value-added and aggregate intermediate input quantities. Primary factors, including land, labor and capital, are fully employed within a period. Land and labor are mobile across activities while capital is activity-specific. Household groups receive income from factor remuneration proportionally to their shares of factor endowment. In addition, they may receive transfers from other household groups, the government and the rest of the world. They spend their income on direct taxes, transfers, and savings and for the consumption of different commodities according to Linear Expenditure System (LES) demand functions, which are derived from maximizing a Stone-Geary utility function. The model uses a Constant Elasticity of Transformation (CET) function to allocate domestic outputs between domestic sales and exports in shares that reflect the ratio of prices in domestic and foreign markets. Armington aggregation of

\footnotetext{
${ }^{4}$ For The Gambia, Guinea Bissau, Liberia and Sierra Leone for which a SAM was not available, a simplified model was used, instead of the CGE model.

${ }^{5}$ See Löfgren et al. (2002) for a detailed description of the static model version and Löfgren (2001) and Thurlow (2004) for dynamic applications of the model.
} 
Table 7 Values of CES and CET elasticities

\begin{tabular}{l|l|l|l}
\hline & $\begin{array}{l}\text { Substitution between } \\
\text { capital, labor and land }\end{array}$ & $\begin{array}{l}\text { Substitution between } \\
\text { imports and domestic sales }\end{array}$ & $\begin{array}{l}\text { Transformation into } \\
\text { exports and domestic sales }\end{array}$ \\
\hline Agriculture & 0.61 & 1.5 & 5.0 \\
\hline Industry & 0.70 & 4.0 & 3.0 \\
\hline Services & 0.80 & 2.5 & 1.2 \\
\hline
\end{tabular}

Source: Based on elasticity estimates found in a broad literature review across developing countries by Annabi et al. (2006)

imports and domestic sales of domestic output determines the composite market supply that should meet the sum of demands for private consumption, government consumption, intermediate input, and investment. Government consumption demands of different commodities are exogenous while government savings adjusts to ensure the equality between government expenditures and revenues. Investment is savings-driven, with fixed marginal propensities to save, a fixed current account deficit and a flexible exchange rate.

The data used to calibrate the DCGE model for individual countries are largely derived from their respective SAMs using an income elasticity of 1.0 for household consumption demand and CES and CET elasticities as summarized in Table 7. As mentioned above, the model's dynamics are recursive, in the sense that the model is run as a repetitive static model while updating some exogenous variables between successive periods such as to replicate the economy's observed long term growth patterns. The rate of changes in population, land use, yields and government expenditures are projected from the series of data available on national accounts and agricultural statistical databases over the last decades. These rates are used to update some exogenous variables, including the LES supernumerary income, land and labor stocks, total factor productivity, and government consumption of the different commodities. In each period, the capital accumulation rate is endogenously determined from investment made during a preceding period and new capital is distributed between sectors proportionally to sectoral capital returns, taking into account a depreciation rate of 0.1 .

This core DCGE model is linked to the microsimulation module in a top-down relationships (i.e., without feedback effects) through a transmission of changes in per capita household expenditures to the country's household survey data, where standard poverty and inequality measures are re-calculated given a defined poverty line.

\section{Mathematical Model Description}

The Tables 8 and 9 below describe the DCGE model utilized for the analysis of growth and poverty reduction scenarios for individual ECOWAS member countries. A comprehensive description of model specifications and closures is provided in Löfgren et al. (2002), Löfgren (2001) and Thurlow (2004). 


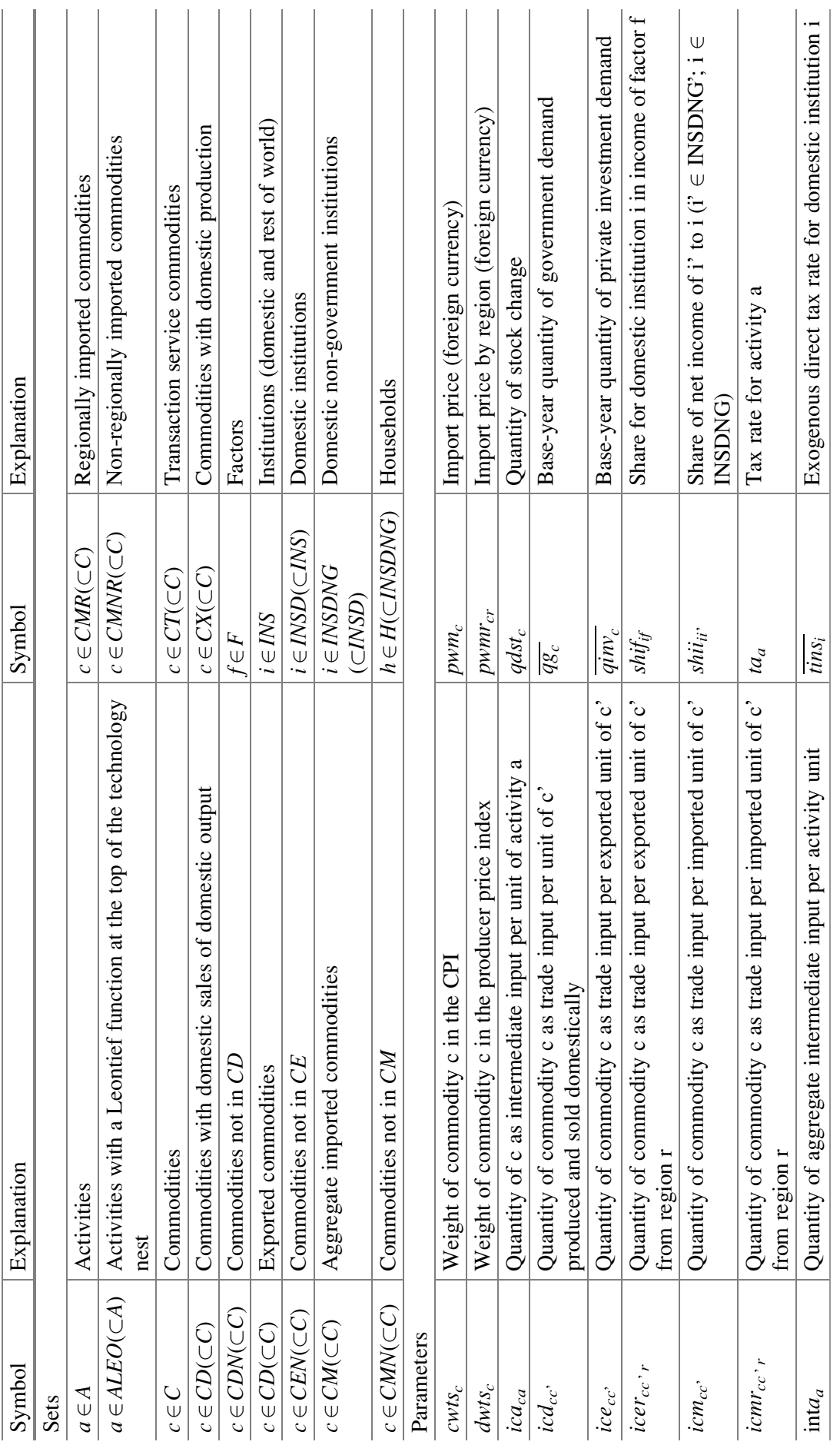




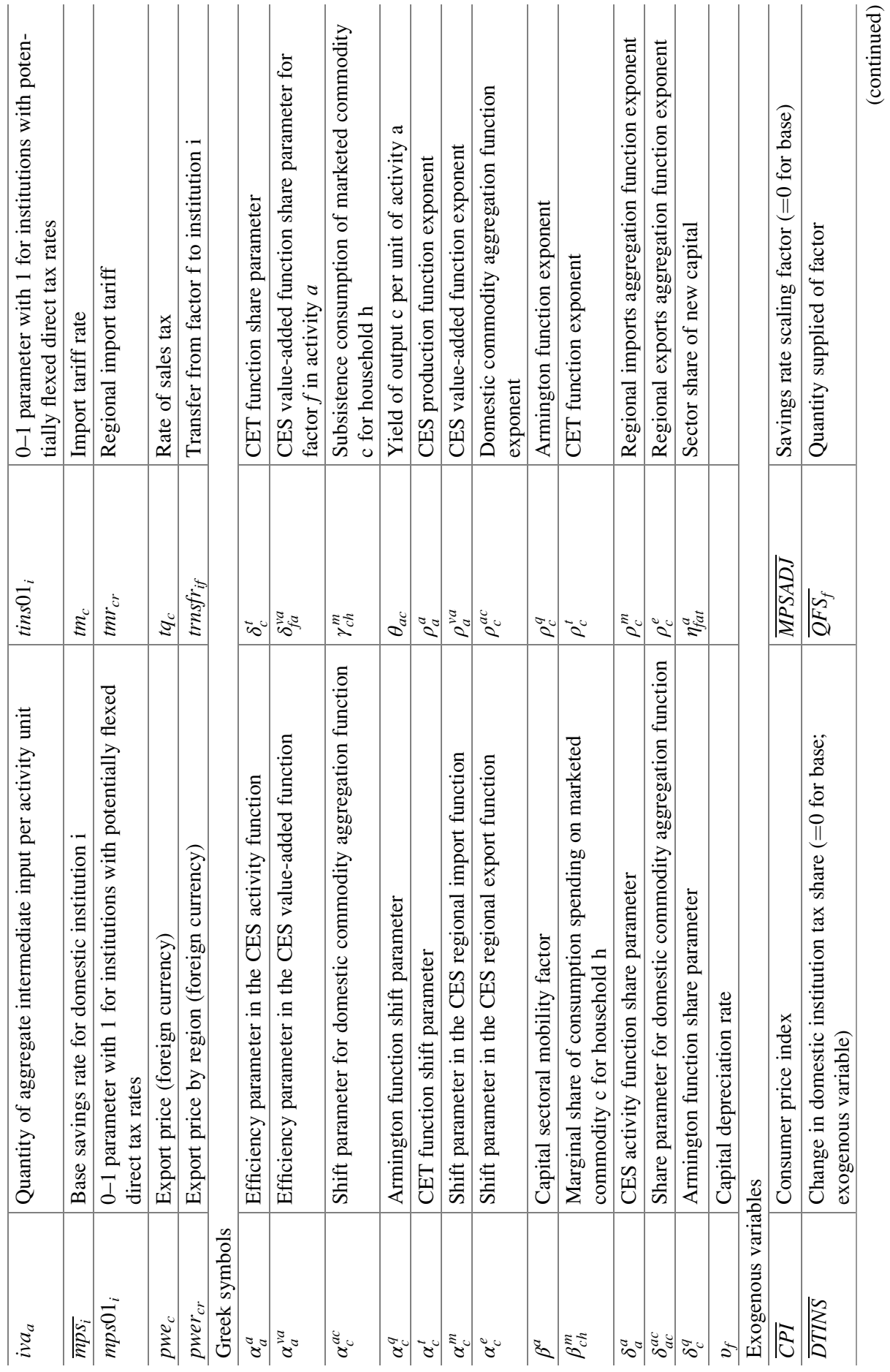




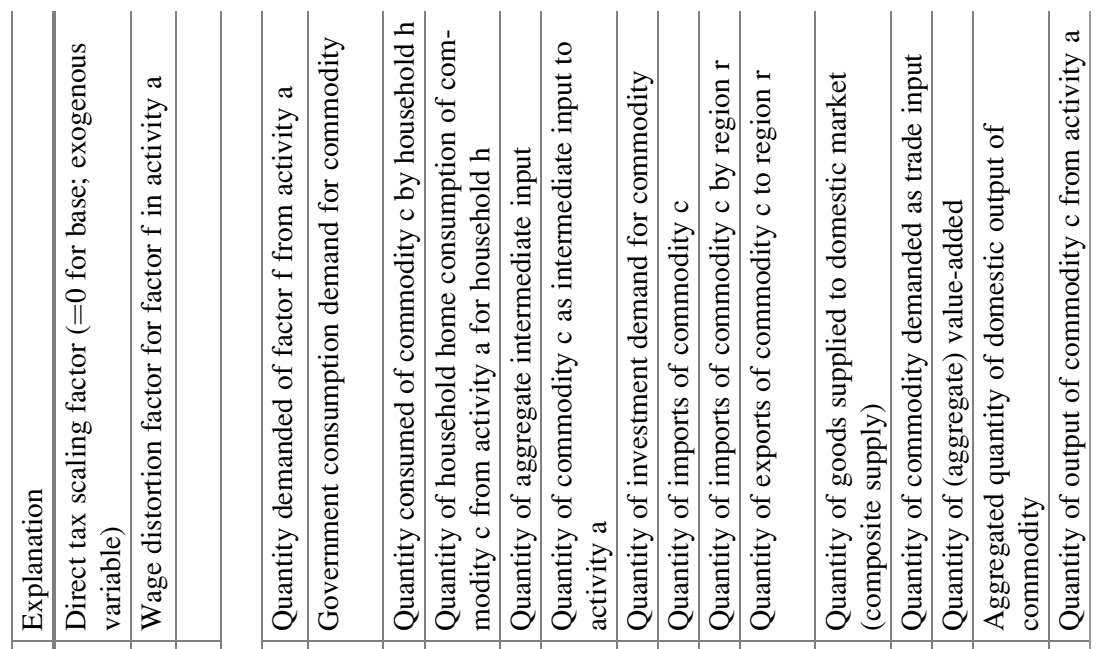

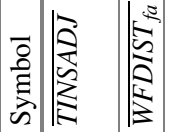

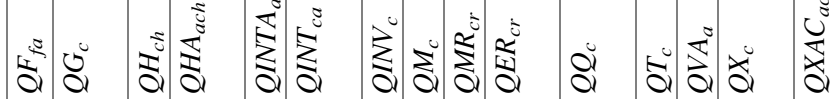

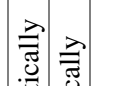




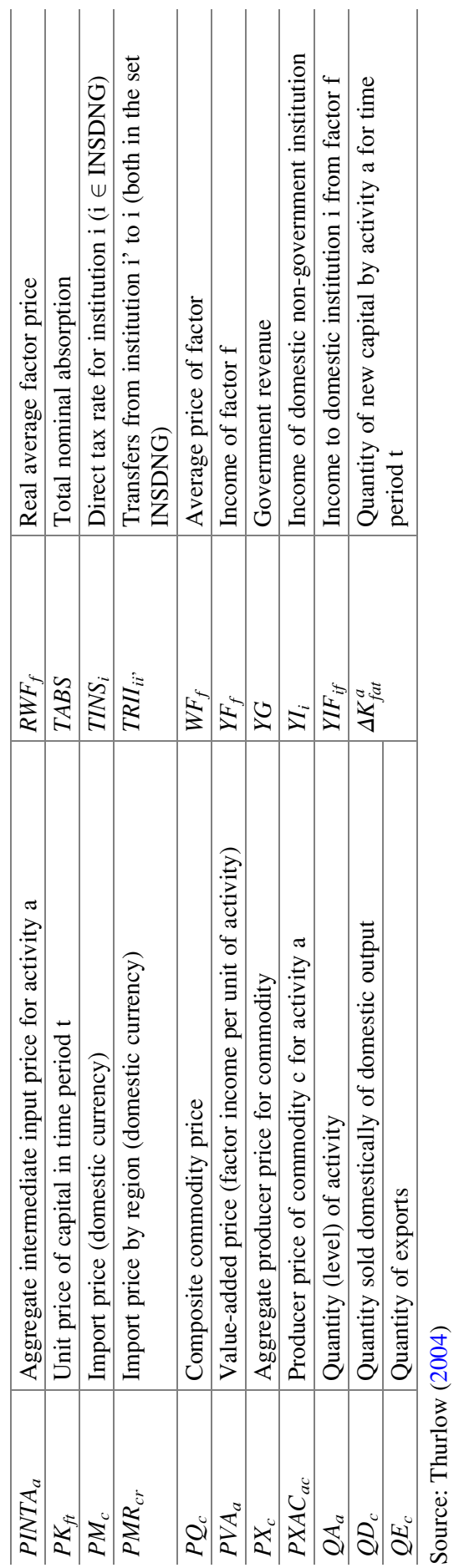


Table 9 Model equations

\begin{tabular}{|c|c|}
\hline Production and price equations & \\
\hline$Q I N T_{c a}=i c a_{c a} \cdot Q I N T A_{a}$ & (1) \\
\hline $\operatorname{PINTA}_{a}=\sum_{c \in C} P Q_{c} \cdot i c a_{c a}$ & $(2)$ \\
\hline$Q V A_{a}=\alpha_{a}^{v a} \cdot\left(\sum_{f \in F} \delta_{f a}^{v a} \cdot\left(\alpha_{f a}^{v a f} \cdot Q F_{f a}\right)^{-\rho_{a}^{v a}}\right)^{-\frac{l}{\rho_{a}^{\frac{1}{a} a}}}$ & (3) \\
\hline $\begin{array}{l}W_{f} \cdot \overline{W F D I S T}_{f a}=P V A_{a} \cdot\left(1-t v a_{a}\right) \cdot Q V A_{a} \cdot \\
\left(\sum_{f \in F^{\prime}} \delta_{f a}^{v a} \cdot\left(\alpha_{f a}^{v a f} \cdot Q F_{f a}\right)^{-\rho_{a}^{v a}}\right)^{-1} \cdot \delta_{f a}^{v a} \cdot\left(\alpha_{f a}^{v a f} \cdot Q F_{f a}\right)^{-\rho_{a}^{v a}-1}\end{array}$ & (4) \\
\hline$Q V A_{a}=i v a_{a} \cdot Q A_{a}$ & (5) \\
\hline$Q I N T A_{a}=i n t a_{a} \cdot Q A_{a}$ & (6) \\
\hline$P A_{a} \cdot\left(1-t a_{a}\right) \cdot Q A_{a}=P V A_{a} \cdot Q V A_{a}+\operatorname{PINTA}_{a} \cdot Q I N T A_{a}$ & (7) \\
\hline$Q X A C_{a c}=\theta_{a c} \cdot Q A_{a}$ & $(8)$ \\
\hline$P A_{a}=\sum_{c \in C} P X A C_{a c} \cdot \theta_{a c}$ & (9) \\
\hline$Q X_{c}=\alpha_{c}^{a c} \cdot\left(\sum_{a \in A} \delta_{a c}^{a c} \cdot Q X A C_{a c}-\rho_{c}^{a c}\right)^{-\frac{1}{\rho_{c}^{c c}-1}}$ & $(10)$ \\
\hline$P X A C_{a c}=P X_{c} \cdot Q X_{c}\left(\sum_{a \in A^{\prime}} \delta_{a c}^{a c} \cdot Q X A C_{a c}^{-\rho_{c}^{a c}}\right)^{-1} \cdot \delta_{a c}^{a c} \cdot Q X A C_{a c}^{-\rho_{c}^{a c}-1}$ & (11) \\
\hline$P E R_{c r}=$ pwer $_{c r} \cdot E X R-\sum_{c^{\prime} \in C T} P Q_{c} \cdot$ icer $_{c^{\prime} c r}$ & (12) \\
\hline$Q E_{c}=\alpha_{c}^{e} \cdot\left(\sum_{r \in R} \delta_{c r}^{e} \cdot\left(Q E R_{c r}\right)^{-\rho_{c}^{e}}\right)^{-\frac{I}{\rho_{c}^{e}}}$ & (13) \\
\hline$\frac{P E R_{c r}}{P E_{c}}=Q E R_{c r} \cdot\left(\sum_{r^{\prime} \in R} \delta_{c r^{\prime}}^{e} \cdot\left(Q E R_{c r^{\prime}}\right)-\rho_{c}^{e}\right)^{-1} \cdot \delta_{c r}^{e} \cdot\left(Q E R_{c r}\right)^{-\rho_{c}^{e}-1}$ & $(14)$ \\
\hline$P E_{c}=p w e_{c} \cdot E X R-\sum_{c^{\prime} \in C T} P Q_{c} \cdot i c e_{c^{\prime} c}$ & $(15)$ \\
\hline$Q X_{c}=\alpha_{c}^{t} \cdot\left(\delta_{c}^{t} \cdot Q E_{c}^{\rho_{c}^{t}}+\left(1-\delta_{c}^{t}\right) \cdot Q D_{c}^{\rho_{c}^{t}}\right)^{\frac{1}{\rho_{c}^{t}}}$ & $(16)$ \\
\hline$\frac{Q E_{c}}{Q D_{c}}=\left(\frac{P E_{c}}{P D S_{c}} \cdot \frac{1-\delta_{c}^{t}}{\delta_{c}^{t}}\right)^{\frac{1}{\rho_{c}^{t}-1}}$ & $(17)$ \\
\hline$Q X_{c}=Q D_{c}+Q E_{c}$ & (18) \\
\hline$P X_{c} \cdot Q X_{c}=P D S_{c} \cdot Q D_{c}+P E_{c} \cdot Q E_{c}$ & $(19)$ \\
\hline$P D D_{c}=P D S_{c}+\sum_{c^{\prime} \in C T} P Q_{c^{\prime}} \cdot i c d_{c^{\prime} c}$ & $(20)$ \\
\hline$P M R_{c r}=p w m r_{c r} \cdot\left(1+t m r_{c r}\right) \cdot \quad E X R-\sum_{c^{\prime} \in C T} P Q_{c} \cdot i c m r_{c^{\prime} c r}$ & $(21)$ \\
\hline$Q M_{c}=\alpha_{c}^{m} \cdot\left(\sum_{r \in R} \delta_{c r}^{m} \cdot\left(Q M R_{c r}\right)^{-\rho_{c}^{m}}\right)^{-\frac{I}{\rho_{c}^{m}}}$ & $(22)$ \\
\hline$\frac{P M R_{c r}}{P M_{c}}=Q M R_{c r} \cdot\left(\sum_{r^{\prime} \in R^{\prime}} \delta_{c r^{\prime}}^{m} \cdot\left(Q M R_{c r^{\prime}}\right)^{-\rho_{c}^{m}}\right)^{-1} \cdot \delta_{c r}^{m} \cdot\left(Q M R_{c r}\right)^{-\rho_{c}^{m}-1}$ & $(23)$ \\
\hline$P M_{c}=p w m_{c} \cdot\left(1+t m_{c}\right) \cdot E X R+\sum_{c^{\prime} \in C T} P Q_{c^{\prime}} \cdot i c m_{c^{\prime} c}$ & $(24)$ \\
\hline$Q Q_{c}=\alpha_{c}^{q} \cdot\left(\delta_{c}^{q} \cdot Q M_{c}^{-\rho_{c}^{q}}+\left(1-\delta_{c}^{q}\right) \cdot Q D_{c}^{-\rho_{c}^{q}}\right)^{-\frac{1}{\rho_{c}^{q}}}$ & $(25)$ \\
\hline$\frac{Q M_{c}}{Q D_{c}}=\left(\frac{P D D_{c}}{P M_{c}} \cdot \frac{\delta_{c}^{q}}{1-\delta_{c}^{q}}\right)^{\frac{l}{I+\rho_{c}^{q}}}$ & $(26)$ \\
\hline$Q Q_{c}=Q D_{c}+Q M_{c}$ & $(27)$ \\
\hline
\end{tabular}


Table 9 (continued)

\begin{tabular}{|c|c|}
\hline \multicolumn{2}{|l|}{ Production and price equations } \\
\hline$P Q_{c} \cdot\left(1-t q_{c}\right) \cdot Q Q_{c}=P D D_{c} \cdot Q D_{c}+P M_{c} \cdot Q M_{c}$ & $(28)$ \\
\hline$Q T_{c}=\sum_{c^{\prime} \in C^{\prime}}\left(i c m_{c c^{\prime}} \cdot Q M_{c^{\prime}}+i c m r_{c c^{\prime}} \cdot Q M R_{c^{\prime}}+i c e_{c c^{\prime}} \cdot Q E_{c^{\prime}}+i c e r_{c c^{\prime}} \cdot Q E R_{c^{\prime}}+i c d_{c c^{\prime}} \cdot Q D_{c^{\prime}}\right)$ & (29) \\
\hline$\overline{C P I}=\sum_{c \in C} P Q_{c} \cdot c w t s_{c}$ & $(30)$ \\
\hline$D P I=\sum_{c \in C} P D S_{c} \cdot d w t s_{c}$ & $(31)$ \\
\hline \multicolumn{2}{|l|}{ Institutional incomes and domestic demand equations } \\
\hline$Y F_{f}=\sum_{a \in A} W F_{f} \cdot \overline{W F D I S T}_{f a} \cdot Q F_{f a}$ & (32) \\
\hline$Y I F_{i f}=$ shif $_{i f} \cdot\left[Y F_{f}-\right.$ trnsfr $\left._{\text {rowf }} \cdot E X R\right]$ & (33) \\
\hline$Y I_{i}=\sum_{f \in F} Y I F_{i f}+\sum_{i \in I N S D N G^{\prime}} T R I I_{i i^{\prime}}+t r n s f r_{i g o v} \cdot \overline{C P I}+t r n s f r_{i r o w} \cdot E X R$ & (34) \\
\hline $\operatorname{TRII}_{i i^{\prime}}=\operatorname{shii}_{i i^{\prime}} \cdot\left(1-\operatorname{MPS}_{i^{\prime}}\right) \cdot\left(1-\overline{\operatorname{tins}}_{i^{\prime}}\right) \cdot Y I_{i^{\prime}}$ & $(35)$ \\
\hline$E H_{h}=\left(1-\sum_{i \in I N S D N G} s h i i_{i h}\right) \cdot\left(1-M P S_{h}\right) \cdot\left(1-\overline{\operatorname{tins}}_{h}\right) \cdot Y I_{h}$ & (36) \\
\hline$P Q_{c} \cdot Q H_{c h}=P Q_{c} \cdot \gamma_{c h}^{m}+\beta_{c h}^{m} \cdot\left(E H_{h}-\sum_{c^{\prime} \in C} P Q_{c^{\prime}} \cdot \gamma_{c^{\prime} h}^{m}\right)$ & $(37)$ \\
\hline$Q I N V_{c}=I A D J \cdot \overline{q i n v}_{c}$ & $(38)$ \\
\hline$Q G_{c}=\overline{G A D J} \cdot \overline{q g_{c}}$ & (39) \\
\hline$E G=\sum_{c \in C} P Q_{c} \cdot Q G_{c}+\sum_{i \in I N S D N G} t r n s f r_{i g o v} \cdot \overline{C P I}$ & $(40)$ \\
\hline $\begin{array}{c}Y G=\sum_{i \in I N S D N G} \overline{\operatorname{tins}_{i}} \cdot Y I_{i}+\sum_{a \in A} t a_{a} \cdot P A_{a} \cdot Q A_{a}+\sum_{c \in C M N R} t m_{c} \cdot p w m_{c} \cdot Q M_{c} \cdot E X R+ \\
\sum_{r \in R} \sum_{c \in C M R} t m r_{c r} \cdot p w m r_{c r} \cdot Q M R_{c r} \cdot E X R+\sum_{c \in C} t q_{c} \cdot P Q_{c} \cdot Q Q_{c}+\sum_{f \in F} Y F_{\text {govf }}+t r n s f r_{\text {gov row }} \cdot E X R\end{array}$ & $(41)$ \\
\hline
\end{tabular}

System constraints and macroeconomic closures

\begin{tabular}{|c|c|}
\hline$Q Q_{c}=\sum_{a \in A} Q I N T_{c} a+\sum_{h \in H} Q H_{c h}+Q G_{c}+Q I N V_{c}+q d s t_{c}+Q T_{c}$ & (42) \\
\hline$\sum_{a \in A} Q F_{f a}=Q F S_{f}$ & (43) \\
\hline$Q F S_{f} /{ }_{Q F S} f^{0}=\left({ }^{R W F_{f}} /_{R W F} f^{0}\right)^{\text {etal } s_{f}}$ & (44) \\
\hline$R W F_{f}=\left(\frac{Y F_{f}}{Q F S_{f}}\right) /\left(\frac{C P I}{C P I^{0}}\right)$ & $(45)$ \\
\hline$Y G=E G+G S A V$ & (46) \\
\hline $\begin{aligned} & \sum_{c \in C M N R} p w m_{c} \cdot Q M_{c}+\sum_{r \in R} \sum_{c \in C M R} p w m r_{c r} \cdot Q M R_{c r} \cdot \sum_{f \in F} t r n s f r_{\text {rowf }} \\
= & \sum_{c \in C E N R} p w e_{c} \cdot Q E_{c}+\sum_{r \in R} \sum_{c \in C E R} p w e r_{c r} \cdot Q E R_{c r}+\sum_{i \in I N S D} t^{\prime r n s f r_{i r o w}}+F S A V\end{aligned}$ & (47) \\
\hline$\sum_{i \in I N S D N G} M P S_{i} \cdot\left(1-\overline{\text { tins }}_{i}\right) \cdot Y I_{i}+G S A V+E X R \cdot F S A V=\sum_{c \in C} P Q_{c} \cdot Q I N V_{c}+\sum_{c \in C} P Q_{c} \cdot q d s t_{c}$ & (48) \\
\hline$M P S_{i}=\overline{m p s}_{i} \cdot(1+M P S A D J)$ & (49) \\
\hline \multicolumn{2}{|l|}{ Capital accumulation and allocation equations } \\
\hline$A W F_{f t}^{a}=\sum_{a}\left[\left(\sum_{a^{\prime}}^{Q F_{f a t}} F_{f a^{\prime} t}\right) \cdot W F_{f t} \cdot W F D I S T_{f a t}\right]$ & $(50)$ \\
\hline$\eta_{f a t}^{a}=\left(\frac{Q F_{f a t}}{\sum_{a^{\prime}} Q F_{f a^{\prime}}}\right) \cdot\left(\beta^{a} \cdot\left(\frac{W F_{f, t}+W F D I S T_{f a t}}{A W F_{f t}^{a}}-1\right)+1\right)$ & (51) \\
\hline$\Delta K_{f a t}^{a}=\eta_{f a t}^{a} \cdot\left(\frac{\sum_{c} P Q_{c t} \cdot Q I N V_{c t}}{P K_{f t}}\right)$ & $(52)$ \\
\hline
\end{tabular}


Table 9 (continued)

\begin{tabular}{l|l}
\hline Production and price equations & \\
\hline$P K_{f t}=\sum_{c} P Q_{c t} \cdot \frac{Q I N V_{c t}}{\sum_{c^{\prime}} Q I N V_{c^{\prime} t}}$ & (53) \\
\hline$Q F_{f a t+1}=Q F_{f a t} \cdot\left(1+\frac{\Delta K_{f a t}^{a}}{Q F_{f a t}}-v_{f}\right)$ & $(54)$ \\
\hline$Q F S_{f t+1}=Q F S_{f t} \cdot\left(1+\frac{\sum_{a} \Delta K_{f a t}}{Q F S_{f t}}-v_{f}\right)$ & $(55)$ \\
\hline
\end{tabular}

Source: Thurlow (2004)

\section{References}

Annabi, N., J. Cockburn, and B. Decaluwé. 2006. Functional forms and parametrization of CGE models. PEP MPIA working papers 2006-04. Québec: Poverty and Economic Policy Research Network.

Badiane, O., S. Odjo, and J. Ulimwengu. 2010. Building capacities for evidence and outcome policy planning and implementation: The example of the Comprehensive Africa Agriculture Development Programme (CAADP). IFPRI Discussion Paper 1019. Washington, DC: International Food Policy Research Institute.

Breisinger, C., X. Diao, J. Thurlow, B. Yu, and S. Kalovali. 2008. Accelerating growth and structural transformation: Ghana's options for reaching middle income country status. IFPRI Discussion Paper 750. Washington, DC: International Food Policy Research Institute.

Diao, X., M. Nwafor, V. Alpuerto, K. Akramov, and S. Salau. 2010. Agricultural growth and investment options for poverty reduction in Nigeria. IFPRI Discussion Paper 954. Washington, DC: International Food Policy Research Institute.

Fan, S., B. Yu, and A. Saurkar. 2008. Public spending in developing countries: Trends, determination, and impact. In Public expenditures, growth and poverty: Lessons from developing countries, ed. S. Fan. Washington, DC and Baltimore, MD: International Food Policy Research Institute and Johns Hopkins University Press.

Löfgren, H. 2001. Less poverty in Egypt? Explorations of alternative pasts with lessons for the future. IFPRI Discussion Paper 72. Washington, DC: International Food Policy Research Institute.

Löfgren, H., R. Harris, and S. Robinson. 2002. A standard CGE model in GAMS. IFPRI Discussion Paper 75. Washington, DC: International Food Policy Research Institute.

Thurlow, J. 2004. A dynamic Computable General Equilibrium (CGE) model for South Africa: Extending the static IFPRI model. Working Paper No. 1-2004. Pretoria: Trade and Industrial Policy Strategies.

World Bank. 2008. World development indicators. Washington, DC: World Bank. http://data. worldbank.org/sites/default/files/wdi08.pdf. Accessed 25 May 2009.

Ousmane Badiane is the Director for Africa at the International Food Policy Research Institute (IFPRI), based in Washington, DC. He oversees the Institute's regional offices for West and Central Africa, in Dakar, Senegal, and Eastern and Southern Africa, in Addis Ababa, Ethiopia. He received a Master's Degree and $\mathrm{PhD}$ in agricultural economics from the University of Kiel in Germany. His awards include being selected as a 2015 Yara Prize Laureate, a Doctoral Degree Honoris Causa from the University of KwaZulu Natal in South Africa and induction as Distinguished Fellow of the African Association of Agricultural Economics. 
Sunday P. Odjo is a Research Coordinator in IFPRI's West and Central Africa Office in Dakar, Senegal.

Fleur Wouterse is a Research Fellow in IFPRI's West and Central Africa Office, and is based in Kampala, Uganda. She holds a PhD in Development Economics from Wageningen University, the Netherlands. Her research mainly takes a micro-economic approach and focuses on households in rural West Africa.

Open Access This chapter is licensed under the terms of the Creative Commons Attribution 4.0 International License (http://creativecommons.org/licenses/by/4.0/), which permits use, sharing, adaptation, distribution and reproduction in any medium or format, as long as you give appropriate credit to the original author(s) and the source, provide a link to the Creative Commons license and indicate if changes were made.

The images or other third party material in this chapter are included in the chapter's Creative Commons license, unless indicated otherwise in a credit line to the material. If material is not included in the chapter's Creative Commons license and your intended use is not permitted by statutory regulation or exceeds the permitted use, you will need to obtain permission directly from the copyright holder. 